MA'ALIM: Jurnal Pendidikan Islam

Volume 1, Nomor 1, Juli 2020

\title{
KOMPARASI HASIL BELAJAR SISWA MENGGUNAKAN STRATEGI MAKE A MATCH DAN CARD SORT MATA PELAJARAN AKIDAH AKHLAK KELAS X MADRASAH ALIYAH
}

\author{
Faridhotul Zahro' \\ IAIN Ponorogo \\ faridhotulzahro@gmail.com
}

\author{
Ju'Subaidi \\ IAIN Ponorogo \\ jusubaidi@gmail.com
}

\begin{abstract}
The purpose of this study was to find out the difference between student learning outcomes using the make a match strategy and Card Sort strategy in the subjects of Akidah Akhlaq on $X$ grade students in Aliyah Madrasah. This research is a quantitative research with comparative analysis. The subjects of this study were 26 X grade students of MA M'arif Balong. Data collection used test instruments, while data analysis techniques used the " $t$ " test analysis formula. The results of this study indicate that students who use the make a match strategy were $69.23 \%$ in the good category, the sufficient category is $0 \%$, and the less category is $30.77 \%$. While the percentage of learning outcomes of students who use the card sort strategy were $46.15 \%$ in the good category, the sufficient category is 0\%, and the less category is 53.85\%. This shows a significant difference between student learning outcomes using the strategy to make a match and card sort strategy. It is proven by the test " $t$ " obtained $t 0=50.55$ at a significant level of $1 \% \mathrm{t} t=2.80$ and at a significant level of 5\% $t t=2.06$ so that $t \_0>t \_t$ means Ha is accepted. It means a strategy of making a match is suitable for Akidah Akhlaq because it can improve student learning outcomes while the card sort strategy is not suitable for use in Akidah Akhlaq.
\end{abstract}

Keywords: Learning outcome, make a match strategy, card sort strategy, subject of akidah akhlaq.

Abstrak: Tujuan penelitian ini adalah untuk mengetahui perbedaan antara hasil belajar siswa yang menggunakan strategi make a match dan strategi Card Sort mata pelajaran akhidah akhlak siswa kelas X di Madrasah Aliyah. Penelitian ini merupakan penelitian kuantitatif dengan analisis komparasional. Subjek penelitian ini adalah siswa kelas X MA M'arif Balong yang berjumlah 26 siswa. Pengumpulan data menggunakan instrumen tes, sedangkan teknik analisa data menggunakan rumus analisis uji "t". Hasil penelitian ini menunjukkan bahwa presentase hasil belajar siswa yang menggunakan strategi make a match adalah 69.23berada pada kategori baik $69,23 \%$, kategori cukup adalah $0 \%$, dan kategori kurang adalah 30,77\%. Sedangkan presentase hasil belajar siswa yang menggunakan strategi card sort adalah 46,15 berada pada kategori baik, kategori cukup adalah $0 \%$, dan kategori kurang adalah 53,85\%. Hal ini menunjukkan adanya perbedaan yang signifikan hasil belajar siswa antara yang menggunakaan menggunakan strategi make a match dan strategi card sort mata pelajaran Akidah Akhlak Kelas X MA. Dibuktikan dengan tes " $\mathrm{t}$ " diperoleh $\mathrm{t}_{0}=50,55$ pada taraf signifikan $1 \% \mathrm{t}_{\mathrm{t}}=2,80$ dan pada taraf signifikan $5 \%$ $\mathrm{t}_{\mathrm{t}}=2,06$ sehingga $t_{0}>t_{t}$ artinya Ha diterima. Berarti strategi make a match lebih cocok digunakan untuk pelajaran akidah akhlak karena dapat meinggkatkan hasil belajar siswa dibandingkan dengan strategi card sort.

Kata kunci: Hasil belajar, materi akidah akhlaq, strategi make a match, strategi card sort. 
MA'ALIM: Jurnal Pendidikan Islam

Volume 1, Nomor 1, Juli 2020

\section{PENDAHULUAN}

Pendidikan adalah suatu proses dalam rangka mempengaruhi siswa agar dapat menyesuaikan diri sebaik mungkin terhadap lingkungannya dan dengan demikian akan menimbulkan perubahan dalam dirinya yang memungkinkannya untuk berfungsi secara kuat dalam kehidupan masyarakat. Pengajaran bertugas mengarahkan proses ini agar sasaran dari perubahan itu dapat tercapai sebagaimana yang diinginkan. ${ }^{1}$

Pendidikan menurut UU No.20 tahun 2003 adalah usaha sadar dan terencana untuk mewujudkan suasana belajar dan proses pembelajaran agar peserta didik secara aktif mengembangkan potensi dirinya untuk memiliki kekuatan spiritual keagamaan. Pengendalian diri, kepribadian, kecerdasan, akidah akhlak, serta ketrampilan yang diperlukan dirinya, masyarakat, bangsa dan Negara. ${ }^{2}$

Belajar mengajar adalah suatu kegiatan yang bernilai edukatif. Nilai edukatif mewarnai interaksi yang terjadi antara guru dengan siswa. Interaksi bernilai edukatif dikarenakan kegiatan belajar mengajar yang dilakukan, diarahkan untuk mencapai tujuan tertentu yang telah dirumuskan sebelum pengajaran dilakukan. Guru dengan sadar merencanakan kegiatan pengajarannya secara sistematis dengan memanfaatkan segala sesuatunya guna kepentingan pengajaran. Harapan yang tidak pernah sirna dan selalu guru tuntut adalah bagaimana bahan pelajaraan yang disampaikan guru dapat dikuasai oleh siswa secara tuntas. ${ }^{3}$

Suatu proses dalam pembelajaran dikatakan memiliki kualitas yang baik, apabila dalam pembelajaran tersebut memenuhi dua hal yakni kesesuaian antara strategi yang digunakan dengan materi yang diajarkan dan hasil yang diperoleh mencapai nilai yang tinggi. Proses adalah kegiatan yang dilakukan oleh siswa dalam mencapai tujuan pengajaran. ${ }^{4}$

Keberhasilan dalam bidang pendidikan melalui proses pembelajaran di sekolah sangat dipengaruhi oleh beberapa faktor di antaranya yaitu peserta didik, kurikulum, tenaga pendidik, sarana dan prasarana, serta faktor lingkungan. Selain itu, juga dipengaruhi oleh kemampuan siswa dan kualitas pengajaran guru dalam menyampaikan materi pelajaran. Pada umumnya, setiap kegiatan belajar akan berakhir dengan hasil belajar. Hasil belajar adalah kemampuan-kemampuan yang dimiliki siswa setelah menerima pengalaman belajarnya. Dalam sistem pendidikan nasional

\footnotetext{
${ }^{1}$ Oemar Hamalik, Proses Belajar Mengajar, (Jakarta: Bumi Aksara, 2012), 79.

${ }^{2}$ Hasbullah, Dasar-dasar Ilmu Pendidikan, (Jakarta: Rajawali, 2009), 4.

${ }^{3}$ Syaiful Bahri Djamarah dan Aswin Zain, Strategi Belajar Mengajar, (Jakarta: PT Renika Cipta, 2010$), 1$.

${ }^{4}$ Nana Sudjana, Penilaian Hasil Proses Belajar Mengajar, (Bandung: PT.Remaja Rosdakarya, 1995), $22-23$.
} 
MA'ALIM: Jurnal Pendidikan Islam

Volume 1, Nomor 1, Juli 2020

rumusan tujuan pendidikan, baik tujuan kurikuler maupun tujuan instruksional, menggunakan klasifikasi hasil belajar dari Benyamin Bloom yang secara garis besar membaginya menjadi tiga ranah, yakni kognitif, afektif, dan psikomotorik. ${ }^{5}$

Hasil belajar Menurut Gange dan Briggs dalam buku Jamil Suprihatiningrum adalah kemampuan-kemampuan yang dimiliki siswa Reigeluth berpendapat bahwa hasil belajar atau pembelajaran dapat juga dipakai sebagai pengaruh yang memberikan suatu ukuran nilai dan metode atau strategi alternatife dalam kondisi yang berbeda. Reigeluth juga mengatakan secara spesifik bahwa hasil belajar adalah suatu kinerja (perfomance) yang diindikasikan sebagai suatu kapabilitas (kemampuan) yang telah diperoleh. ${ }^{6}$

Hasil belajar sangat erat kaitannya dengan belajar atau proses belajar. Hasil belajar pada sasarannya dikelompokkan dalam dua kelompok, yaitu pengetahuan dan ketrampilan. Pengetahuan dibedakan menjadi empat macam, yaitu pengetahuan tentang fakta-fakta, pengetahuan tentang prosedur, pengetahuan konsep, dan ketrampilan untuk berinteraksi. ${ }^{7}$

Menurut Suprijono, Hasil Belajar adalah pola-pola perbuatan, nilai-nilai, pengertian, sikapsikap, apersepsi, dan keterampilan. ${ }^{8}$ Hasil belajar yaitu perubahan-perubahan yang terjadi pada diri siswa, baik yang menyangkut aspek kognitif, afektif, psikomotorik sebagai hasil dari kegiatan belajar. Anak yang berhasil dalam belajar adalah yang berhasil mencapai tujuan-tujuan pembelajaran atau tujuan intruksional. ${ }^{9}$

Menurut Bloom dalam buku Muhammad Thobroni hasil pembelajaran mencakup kemampuan kognitif, efektif, dan psikomotorik. Adapun menurut Lindgren hasil pembelajaran meliputi kecakapan, informasi, pengertian dan sikap. Dengan demikian, dapat disimpulkan bahwa hasil belajar adalah perubahan perilaku secara keselurahan bukan hanya salah satu aspek potensi kemanusiaan saja. ${ }^{10}$ Dari beberapa pendapat di atas dapat disimpulkan bahwa hasil belajar adalah perubahan sikap atau perilaku siswa setelah mengikuti proses belajar mengajar, dan kemampuankemampuan yang dimiliki siswa setelah menerima pengalaman belajar.

${ }^{5}$ Nana Sudjana, Penilaian Hasil Proses Belajar Mengajar, 22.

${ }^{6}$ Jamil Suprihatiningrum, Strategi Pembelajaran: Teori dan Aplikasi, (Jogjakarta: Ar-Ruzz Media, 2013), 37.

${ }^{7}$ Ibid., 37

${ }^{8}$ Muhammad Thobroni \& Arif Mustofa, Belajar dan Pembelajaran Pengembangan Wacana dan Praktik Pembelajaran dalam Pembangunan Nasional, (Jogjakarta: Ar-Ruzz Media, 2012), 22.

${ }^{9}$ Ahmad Susanto, Teori Belajar dan Pembelajaran di Sekolah Dasar, (Jakarta: Kencana,2013), 5.

${ }^{10}$ Muhammad Thobroni \& Arif Mustofa, Belajar dan Pembelajaran Pengembangan Wacana dan Praktik Pembelajaran dalam Pembangunan Nasional, 23-24. 
MA'ALIM: Jurnal Pendidikan Islam

Volume 1, Nomor 1, Juli 2020

Untuk mengetahui perubahan perilaku siswa secara keseluruhan maka diperlukan penilaian proses pembelajaran. Saat ini proses pembelajaran di Indonesia dapat dikatakan masih lemah. Orientasi pembelajaran biasanya terpusat pada guru sehingga membuat siswa menjadi pasif padahal strategi pembelajaran yang digunakan guru seharusnya membuat siswa lebih aktif

Berdasarkan observasi awal peneliti menemukan beberapa hal yang terkait dengan proses pembelajaran berlangsung, strategi yang digunakan guru kurang bervariasi sehingga siswa merasa jenuh terhadap proses pembelajaran tersebut, kurangnya media pembelajaran yang digunakan sehingga pembelajaran kurang menarik, kurangnya dalam pengelolaan kelas sehingga suasana kelas menjadi kurang menyenangkan, guru juga kurang membangkitkan minat dan memberikan motivasi belajar sisiwa, serta penggunaan waktu kurang tepat. Selain itu selama proses pembelajaran akidah akhlak, mayoritas siswa kelas X MA Ma'arif Balong Ponorogo, terlihat kurang berpartisipasi dalam kegiatan pembelajaran. Buktinya saat guru memberikan kesempatan kepada siswa untuk bertanya atau berpendapat tidak ada satupun siswa yang mau bertanya ataupun menyampaikan pendapat. Namun setelah guru mengadakan evaluasi pembelajaran dengan tes tulis, mayoritas siswa memperoleh nilai dibawah standar. Kriteria Ketuntasan Minimal (KKM) pada Mata Pelajaran Akidah Akhlak yaitu 75, terdapat sebagaian siswa yang belum tuntas atau masih kurang. Artinya hasil belajar siswa kelas X MA Ma'arif Balong dapat dikatakan masih rendah. Oleh karena itu diperlukan strategi pembelajaran yang tepat yang mampu mendorong siswa untuk lebih berperan aktif daalam kegiatan pembelajaran karena strategi pembelajaran memengaruhi hasil belajar siswa. ${ }^{11}$

Belajar adalah proses bagi peserta didik dalam membangun gagasan atau pemahaman sendiri. Kegiatan pembelajaran seharusnya memberikan kesempatan kepada peserta didik untuk melakukan proses belajarnya secara mudah, lancar, dan termotivasi. Karena itu pula suasana belajar yang diciptakan guru seharusnya melibatkan peserta didik secara aktif misalnya mengamati, meneliti, bertanya dan mempertanyakan, menjelaskan, dan mencari contoh. Melalui strategi pembelajaran aktif diharapkan dapat menjadikan alternatif bagi guru untuk mengaktifkan peserta didik baik secara individu maupun kelompok. ${ }^{12}$

Dewasa ini kita dikenalkan dengan berbagai macam strategi pembelajaran aktif yang dapat diaplikasikan dalam proses pembelajaran seperti strategi Jigsaw Learning (Belajar model jigsaw),

\footnotetext{
${ }^{11}$ Hasil observasi, Selasa, 21 Maret 2017, Di MA Ma’arif Balong Ponorogo.

${ }^{12}$ Ismali, Strategi Pembelajaran Agama Berbasis Paikem (Semarang: Rasail Media Group, 2008), 71-72.
} 
MA'ALIM: Jurnal Pendidikan Islam

Volume 1, Nomor 1, Juli 2020

Active Knowledge sharing (saling tukar pengetahuan), make a match (mencari pasangan), team quiz (quiz kelompok), Giving Question and getting answers (memberi pertanyaan dan menerima jawaban), card sort (sortir kartu), random teks (teks acak) dan lain sebagainya. ${ }^{13}$

Dalam penelitian ini peneliti akan meneliti tentang strategi yang berkaitan dengan kegiatan belajar mengajar. Dalam proses pembelajaran diaplikasikan dalam strategi make a match (mencari pasangan) dan card sort (sortir kartu). Kedua strategi tersebut pada dasarnya memiliki atau perlakuan yang hampir sama meskipun tujuan dasarnya berbeda, sama-sama menggunkan kartu.

Strategi pembelajaran aktif make a match (mencari pasangan) merupakan salah satu alternatif yang dapat digunakan untuk meningkatkan hasil belajar siswa. Strategi make a match adalah pembelajaan menggunakan kartu-kartu, kartu-kartu tersebut terdiri dari kartu yang berisi soal dan kartu yang lainya berisi jawaban dari soal-soal tersebut. ${ }^{14}$

Teknik belajar mengajar mencari pasangan (make a match) dikembangkan oleh Lorna Curran. Teknik ini bisa digunakan dalam semua mata pelajaran, salah satunya yaitu mata pelajaran akidah akhlak. ${ }^{15}$ Sedangkan strategi kartu sortir (card sort) ini membuat peserta didik bergerak secara aktif dan dinamis mencari pasangan-pasangan kartu, strategi ini sangat cocok digunakan untuk mereview pengetahuan atau untuk mengerjakan konsep, klasifikasi, fakta dan karakteristik hal tertentu. ${ }^{16}$ Dalam proses belajar mengajar di kelas siswa yang sebelumnya pasif, seperti pendiam, ramai dengan teman, bermain sendiri menjadi lebih aktif untuk bertanya, dan suasana kelas yang sebelumnya membosankan menjadi lebih aktif ketika strategi make a match dan card sort diterapkan di dalam kelas. Setelah menggunakan strategi make a match dan card sort hasil belajar akidah akhlak menjadi lebih baik dari sebelum menggunakan strategi tersebut.

Penelitian ini bertujuan untuk mengetahui apakah ada perbedaan yang signifikan hasil belajar siswa antara yang menggunakan strategi make a match dengan strategi card sort untuk mmata pelajaran akidah akhlakk kelas X Madrasah Aliyah.

\section{METODE}

\footnotetext{
${ }^{13}$ Hisyam Zaini, Strategi Pembelajaran Aktif, (Yogyakarta: Pustaka Insan Madani, 2008), 50.

${ }^{14}$ Ridwan Abdullah Sani, Inovasi Pembelajaran, (Jakarta: Bumi Aksara, 2013), 196.

${ }^{15}$ Syaiful Bahri Djamarah, Guru dan Anak Didik Dalam Interaksi Edukatif Suatu Pendekatan Teoritis Psikologis, 402.

${ }^{16}$ Muhammad Thobroni, Belajar dan Pembelajaran Pengembangan Wacana dan Praktik Pembelajaran dalam Pembangunan Nasional, 286.
} 
MA'ALIM: Jurnal Pendidikan Islam

Volume 1, Nomor 1, Juli 2020

Dalam penelithan ini, peneliti menggunakan pendekatan kuantitatif, dengan teknik analisis komparasional. Rancangan penelitian ini terdiri dari 2 variabel. Dalam penelitian ini yang merupakan variabel dependen atau variabel terikat adalah hasil belajar siswa (variabel Y) sedangkan yang menjadi variabel independen atau variabel bebas adalah startegi make a match (variabel X1) dan strategi card sort (variabel X2). Penelitian dilakukan dengan melakukan pengendalian dan pengamatan terhadap kelas eksperimen 1 yang diajar menggunkan strategi make a match dan kelas eksperimen 2 yang diajar menggunkan strategi card sort. Rincian mengenai rancangan penelitian yang akan dilaksanakan dapat dilihat pada tabel 3.1.

Tabel 3.1 Pedoman Perlakuan Penelitihan

\begin{tabular}{ccc}
\hline Kelas & Perlakuan & Postest \\
\hline \hline Eksperimen 1 & $\mathrm{X} 1$ & $\mathrm{Y}$ \\
\hline Eksperimen 2 & $\mathrm{X} 2$ & $\mathrm{Y}$ \\
\hline
\end{tabular}

Keterangan:

X1 : Kelas yang menggunkan strategi make a match

X2 : Kelas yang menggunakan strategi card sort

Y1 : hasil belajar siswa yang menggunkan strategi make a match

Y2 : hasil belajar yang menggunkan strategi card sort

Strategi tersebut akan diterapkan satu kali sesuai dengan rencana pelaksanaan pembelajaran (RPP) yang telah dibuat. Materi yang akan digunakan adalah materi Bab V "Akhlak Tercela”. Subjek penelitihan ini adalah seluruh siswa kelas X MA Ma'arif Balong Ponorogo yang berjumlah 26 siswa. Instrumen pengumpulan data pada penelitian ini menggunakan metode tes dengan instrumen soal tes. Soal tes terdiri dari 20 butir soal pilihan ganda untuk mengukur hasil belajar strategi card short dan 20 butir soal pilihan ganda untuk mengukur hasil belajar strategi make a match. Untuk menganalisis data yang telah terkumpul, dalam penelitian ini akan digunkan teknik analisis komparasional bivariat dengan menggunakan rumus tes " $\mathrm{t}$ ". 
MA'ALIM: Jurnal Pendidikan Islam

Volume 1, Nomor 1, Juli 2020

\section{HASIL}

\section{Analisis Deskriptif}

Jumlah siswa yang digunakan dalam penelitian diambil satu kelas yang berjumlah 13 siswa untuk dites setelah diajar menggunakan strategi make a match, serta satu kelas yang terdiri dari 13 siswa yang dites setelah diajar menggunakan strategi card sort dengan soal yang sama. Berikut adalah deskripsi data hasil belajar masinng-masing kelompok:

Tabel 1. Hasil belajar siswa yang menggunakan strategi Make a match

\begin{tabular}{cc}
\hline Nilai & Frekuensi \\
\hline 100 & 6 \\
\hline 92 & 3 \\
\hline 85 & 1 \\
\hline 69 & 2 \\
\hline 61 & 1 \\
\hline \hline Total & 13 \\
\hline
\end{tabular}

Tabel 2. Hasil belajar siswa yang Menggunkaan strategi card sort

\begin{tabular}{cc}
\hline Nilai & Frekuensi \\
\hline 77 & 5 \\
\hline 69 & 1 \\
\hline 54 & 3 \\
\hline 46 & 3 \\
\hline 38 & 1 \\
\hline \hline Total & 13 \\
\hline
\end{tabular}

\section{Analisis Uji Komparasi}

Sebelum melakukan analisis data harus diketahui bahwa data berdistribusi normal dan bersifat homogen. Dari hasil perhitungan uji normalitas dengan rumus lilifors, diketahui bahwa hasil belajar siswa berdistribusi normal. Hal ini dibuktikan dengan nilai $L_{\text {maksimum }}<L_{\text {tabel }}$,

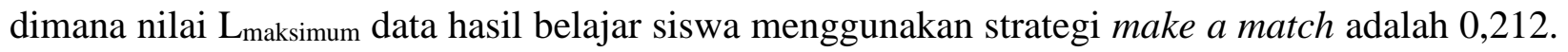

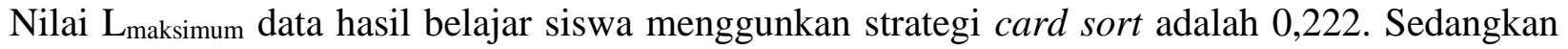
nilai Ltabel pada taraf signifikansi 5\% adalah 0,234, sehingga Ho diterima yang artinya data berdistribusi normal.Selain itu, dari perhitungan uji homogenitas dengan rumus Harley diketahui F (max) hitung sebesar 0,873 kemudian dikonsultasikan dengan F (max) tabel.Pada taraf 
MA'ALIM: Jurnal Pendidikan Islam

Volume 1, Nomor 1, Juli 2020

signifikansi $5 \%$ diketahui nilai $\mathrm{F}(\max )$ tabel 2,95 sehingga $F_{\text {max }}$ hitung $<F_{\text {max }}$ tabel $(0,873<$ 2,675) maka Ho diterima artinya data homogen.

Untuk memperoleh data nilai hasil belajar siswa kelas X MA Ma'arif Balong Ponorogo, peneliti menggunakan teknik tes berupa soal pilihan ganda yang disebarkan pada dua kelas ynag masing-masing kelas berjumlah 13 siswa. Adapun data yang peneliti peroleh dari dua kelas tersebut adalah siswa yang menggunakan strategi make a match dan siswa yang menggunkan strategi card sort, dapat dilihat pada tabel 3.

Tabel 3. Hasil Belajar Siswa Menggunakan Strategi Make a match dan Menggunkan Strategi Card sort

\begin{tabular}{ccc}
\hline Nomor & Strategi make a match & Strategi card sort \\
\hline \hline 1 & 85 & 46 \\
\hline 2 & 100 & 77 \\
\hline 3 \\
\hline 4 \\
\hline 5 \\
\hline 6 \\
\hline 7 \\
\hline 8 \\
\hline 9 \\
\hline 100 & 77 \\
\hline 10 & 100 & 54 \\
\hline 11 & 100 & 53 \\
\hline 12 & 100 & 46 \\
\hline 13 & 61 & 77 \\
\hline & 69 & 54 \\
\hline 92 & 77 \\
\hline 100 & 77 \\
\hline 92 & 38 \\
\hline 69 & 69 \\
\hline
\end{tabular}

Hasil belajar pada mata pelajaran Akidah akhlak dari kedua kelas tersebut, perlu adanya perangkingan nilai. Perangkingan ini menggunakan penyusunan rangking berdasarkan mean dan standar deviasi. Lebih spesifik lagi penyusunan rangking ini menggunkan penyusunan kedudukan atas rangking. Patokan untuk menentukan kategori rangking adalah sebagai berikut:

Kategori rangking atas

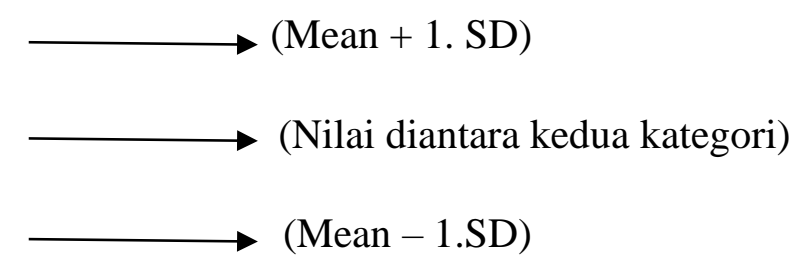

Kategori rangking bawah 
MA'ALIM: Jurnal Pendidikan Islam

Volume 1, Nomor 1, Juli 2020

Tabel 4. Kategori Hasil Belajar Siswa Menggunakan Strategi Make a match

\begin{tabular}{cccccc}
\hline No. & Nilai siswa & Frekuensi & Prosentase & Kategori \\
\hline 1 & $>90,58$ & 9 & $69,23 \%$ & Baik \\
\hline 2 & $87,88-90,58$ & - & $0 \%$ & Cukup \\
\hline 3 & $<87,88$ & 4 & $30,77 \%$ & Kurang \\
\hline & $\sum$ & $\mathbf{1 3}$ & $\mathbf{1 0 0 \%}$ & - \\
\hline
\end{tabular}

Dari tabel tersebut dapat diambil kesimpulan bahwa hasil belajar siswa menggunakan strategi make a match dengan kategori baik berjumlah 9 siswa dengan presentase 69,23\%, kategori cukup berjumlah 0 dengan presentase $0 \%$, dan kategori kurang berjumlah 4 siswa dengan presentase $30,77 \%$.

Tabel 5. Kategori Hasil Belajar Siswa menggunakan Strategi Card Sort

\begin{tabular}{ccccc}
\hline No. & Nilai siswa & Frekuensi & Prosentase & Kategori \\
\hline 1 & $>62,31$ & 6 & $46,15 \%$ & Baik \\
\hline 2 & $59,52-62,31$ & - & $0 \%$ & Cukup \\
\hline 3 & $<59,52$ & 7 & $53,85 \%$ & Kurang \\
\hline & $\sum$ & $\mathbf{1 3}$ & $\mathbf{1 0 0 \%}$ & - \\
\hline
\end{tabular}

Dari tabel tersebut dapat diambil kesimoulan bahwa hasil belajar siswa menggunakan card sort dengan kategori baik berjumlah 6 siswa dengan presentase 46,15\%, kategori cukup berjumlah 0 dengan presentase $0 \%$, dan kategori kurang berjumlah 7 siswa dengan presentase $53,85 \%$.

- Komparasi Hasil Belajar Siswa antara yang Menggunakan Strategi Make a match dengan yang Menggunkan Strategi Card Sort

Melihat perhitungan analisis dari kedua data diketahui:

$\mathrm{M}_{1}=89,23, \mathrm{M}_{2}=60,92, \mathrm{SE}_{\mathrm{m} 1}=0,38970985$ dan $\mathrm{SE}_{\mathrm{m} 2}=0,402163772$. Sehingga untuk mencari standar error perbedaan antara dua variabel adalah:

$$
\begin{aligned}
S E_{m_{1}}-m_{2}= & \sqrt{S E_{m_{1}}^{2}+S E_{m_{2}}^{2}} \\
& =\sqrt{0,38970985^{2}+0,402163772^{2}} \\
& =\sqrt{0,151873767+0,161735699} \\
& =\sqrt{0,313609466}
\end{aligned}
$$


MA'ALIM: Jurnal Pendidikan Islam

Volume 1, Nomor 1, Juli 2020

$$
\begin{aligned}
& =0,560008451 \\
& =0,560
\end{aligned}
$$

Dilanjutkan dengan menghitung besarnya to dengan rumus:

$$
\begin{aligned}
t_{0}=\frac{m_{1}-m_{2}}{S E_{m_{1}}-S E_{m_{2}}} & =\frac{89,23-60,92}{0,560} \\
& =\frac{28,31}{0,560} \\
& =50,55357143 \\
& =50,55
\end{aligned}
$$

Jadi, hasil to diperoleh sebesar 50,55. Langkah selanjutnya adalah menguji hipotesis dengan mengkonsultasikan nilai to dengan $t_{t}$.jika pada taraf signifikansi 5\% $t_{0}>t_{t}$ maka Ho ditolak dan Ha diterima. Jika pada taraf signifikansi $1 \% t_{0}>t_{t}$ maka Ho ditolak dan Ha diterima. Nilai $\mathrm{t}_{\mathrm{t}}$ diperoleh $\mathrm{db}\left(\mathrm{n}_{1}+\mathrm{n}_{2}\right)-2=(13+13)-2=24$. Pada taraf signifikansi $5 \%$ diperoleh $\mathrm{t}_{\mathrm{t}}=2,06$ dan pada taraf signifikansi $1 \%$ diperoleh $\mathrm{t}_{\mathrm{t}}=2,80$. Sedangkan nilai $\mathrm{t}_{0}=$ 50,55. Jadi, pada taraf signifikansi 5\% maupun $1 \%$ lebih besar dari pada $t_{t}$, sehingga Ha diterima dan Ho ditolak, Artinya ada perbedaan yang signifikan hasil belajar siswa yang menggunkan strategi make a match dengan yang menggunkan strategi card sort.

\section{DISKUSI}

Dalam penelitian ini, penulis membandingkan dua hal yang menjadi pokok bahasan yaitu strategi make a match dan strategi card sort dan komparasi hasil belajar siswa menggunakan strategi make a match dengan card sort mata pelajaran akidah akhlak kelas X MA Ma'arif Balong ponorogo tahun pelajaran 2016/2017. Untuk mengetahui adanya perbedaan yang signifikan diantara keduanya peneliti melakukan uji tes dengan menggunakan instrument soal tes yang sudah dianalisis validitas dan reliabilitasnya. Dari hasil tes itu kemudian diuji normalitas dan homogenitasnya sehingga diketahui data berdistribusi normal dan bersifat homogen.

Dalam pembahasan tentang strategi make a match, penulis menggumpulkan data dengan cara menggunakan soal tes yang diisi oleh siswa kelas X MA Ma'arif Balong. Dari pengkategorian dapat diketahui strategi make a macth di MA Ma'arif Balong Ponorogo dijelaskan bahwa hasil belajar siswa lebih dari 90 ada 9 responden dengan prosentase $69,23 \%$ yang termasuk dalam 
MA'ALIM: Jurnal Pendidikan Islam

Volume 1, Nomor 1, Juli 2020

kategori baik. Hasil belajar siswa antara 87-90 ada 0 responden dengan prosentase 0\% yang termasuk dalam kategori cukup, sedangkan hasil belajar siswa kurang dari 87 ada 4 responden dengan prosentase 30,77\% yang termasuk dalam kategori kurang. Sehingga, strategi make a match termasuk dalam kategori baik dengan presentase 69,23\% dengan frekuensi 9.

Dan dalam pembahasan tentang strategi card sort, penulis menggumpulkan data dengan cara menggunakan soal tes yang diisi oleh siswa kelas X MA Ma'arif Balong. Dari pengkategorian dapat diketahui strategi card sort di MA Ma'arif Balong Ponorogo dijelaskan bahwa hasil belajar siswa lebih dari 62 ada 6 responden dengan prosentase 46,15\% yang termasuk dalam kategori baik. Hasil belajar siswa antara 59-62 ada 0 responden dengan prosentase 0\% yang termasuk dalam kategori cukup, sedangkan hasil belajar siswa kurang dari 59 ada 7 responden dengan prosentase $53,85 \%$ yang termasuk dalam kategori kurang. Sehingga, strategi card sort termasuk dalam kategori kurang dengan presentase 53,85\% dengan frekuensi 7.

Berdasarkan hasil penelitian menunjukkan bahwa nilai rata-rata hasil belajar siswa kelas $\mathrm{X}$ pada mata pelajaran akidah akhlak yang menggunakan strategi make a match adalah 89,23, sedangkan yang menggunakan strategi card sort adalah 60,92. Dari hasil tersebut dapat diambil kesimpulan bahwa hasil belajar siswa menggunakan strategi make a match lebih baik dari siswa menggunakan strategi card sort.

Selain itu, dari hasil perhitungan menggunkana rumus uji " $\mathrm{t}$ " diperoleh $\mathrm{t}_{0}$ sebesar 50,55. Diketahui bahwa responden yang diteliti berjumlah 26 responden sehingga ntuk analisa interpretasinya yaitu dengan dp $\left(\mathrm{n}_{1}+\mathrm{n}_{2}\right)-2=(13+13)-2=24$. Dengan taraf signifikansi $5 \%$ maka diperoleh $t_{t}=2,06$ dan analisis hipotesisi diperoleh $t_{0}=50,55$ sehingga sehingga $t_{0}$ lebih besar dari $\mathrm{t}_{\text {tabel }}$ atau $t_{0}>t_{t}(50,55>2,06)$. Sehingga maka Ha diterima dan ho di tolak. Dengan demikian, hipotesis yang diajukan dalam penelitian ini yakni Ha yang berbunyi ada perbedaan yang signifikan hasil belajar siswa menggunakan strategi make a match dengan card sort mata pelajaran akidah akhlak kelas X MA Ma'arif Balong Ponorogo tahun pelajaran 2016/2017.

Dari penjelasan di atas bahwa strategi make a match cocok digunakan pada mata pelajaran akidah akhlak di MA Ma'arif Balong Ponorogo karena dapat meningkatkan hasil belajar siswa. Strategi make a match juga bisa digunakan untuk membangkitkan semangat aktivitas siswa dalam belajar dan dapat digunakan untuk mengulang kembali materi yang sudah diajarkan dalam bentuk permainan. Hal tersebut ditunjukan dengan antusias siswa dalam mengikuti pembelajaran, 
MA'ALIM: Jurnal Pendidikan Islam

Volume 1, Nomor 1, Juli 2020

misalnya seperti keaktifan siswa dalam bertanya atau menjawab pertanyaan di dalam kelas dan keinginan siswa dalam mengikuti pembelajaran akidah akhlak. Berarti strategi make a match mampu untuk memahamkan siswa dalam pembelajaran akidah akhlak. Sedangkan strategi card sort tidak cocok digunakan mata pelajaran akidah akhlak di MA Ma'arif Balong Ponorogo. Hal tersebut ditunjukan dengan nilai siswa yang masih belum tuntas dengan prosentase $53.85 \%$ dan dalam proses pembelajaaran hanya sebagain siswa saja yang aktif mengikuti kegiatan. Mungkin disebab karena kurangnya kerja sama antar siswa dalam proses pembelajaran, dan akhirnya hasil belajar siswa tersebut belum tuntas. Berarti strategi card sort tidak mampu untuk memahamkan siswa dalam pembelajaran akidah akhlak.

\section{KESIMPULAN}

Presentase hasil belajar siswa yang menggunakan strategi make a match pada mata pelajaran Akidah Akhlak Kelas X MA Ma'arif Balong Ponorogo tahun pelajaran 2016/2017 dengan kategori baik adalah 69,23\%, kategori cukup adalah 0\%, dan kategori kurang adalah $30,77 \%$. Presentase hasil belajar siswa yang menggunakan strategi card sort pada mata pelajaran Akidah Akhlak Kelas X MA Ma'arif Balong Ponorogo tahun pelajaran 2016/2017 dengan kategori baik adalah 46,15\%, kategori cukup adalah 0\%, dan kategori kurang adalah 53,85\%.

Ada perbedaan yang signifikan hasil belajar siswa antara yang menggunakaan strategi make a match dengan strategi card sort pada mata pelajaran Akidah Akhlak Kelas X MA Ma'arif Balong Ponorogo tahun pelajaran 2016/2017. Pernyataan ini didasarkan atas perhitungan hipotesis yang menyatakan bahwa baik pada taraf signifikansi 5\% maupun 1\% Ho ditolak atau Ha diterima. Dibuktikan dengan uji tes " $\mathrm{t}$ " diperoleh $t_{0}>t_{t}$ dimana $\mathrm{t}_{0}=50,55$. Sedangkan $\mathrm{t}_{\mathrm{t}}$ pada taraf signifikansi $5 \% \mathrm{t}_{\mathrm{t}}=2,06$ dan pada taraf signifikansi $1 \% \mathrm{t}_{\mathrm{t}}=2,80$.

Berdasarkan hasil penelitian ini, disarankan bagi guru hendaknya lebih kreatif menciptakan suasana belajar yang kondusif dengan menerapkan strategi pembelajaran yang cocok untuk siswa. Selain itu guru juga harus bisa memilih strategi mana yang cocok digunakan untuk mata pelajaran tersebut. Sehingga dalam proses pembelajaran siswa tidak merasa terbebani, bosan dan monoton. Jika strategi tersebut tidak cocok digunakan dalam pelajaran akidah akhlak maka guru harus bisa memilih strategi pembelajaran lain yang cocok digunakan pada mata pelajaran akidah akhlak. 
MA'ALIM: Jurnal Pendidikan Islam

Volume 1, Nomor 1, Juli 2020

\section{DAFTAR PUSTAKA}

Djamarah, Syaiful Bahri \& Aswin Zain. 2010. Strategi Belajar Mengajar. Jakarta: PT Renika Cipta.

Djamarah, Syaiful Bahri. 2010. Guru dan Anak Didik Dalam Interaksi Edukatif Suatu Pendekatan Teoritis Psikologis. Jakarta: Rineka Cipta.

Hamalik, Oemar. 2012. Proses Belajar Mengajar.Jakarta: Bumi Aksara.

Hasbullah. 2009. Dasar-dasar Ilmu Pendidikan. Jakarta: Rajawali.

Ismali. 2008. Strategi Pembelajaran Agama Berbasis Paikem. Semarang: Rasail Media Group.

Sani, Ridwan Abdullah. 2013. Inovasi Pembelajaran. Jakarta: Bumi Aksara.

Sudjana, Nana. 1995. Penilaian Hasil Proses Belajar Mengajar. Bandung: PT. Remaja Rosdakarya.

Sudjana, Nana. 2009. Penilaian Hasil Proses Belajar Mengajar. Bandung: Remaja Rosda Karya.

Suprihatiningrum, Jamil. 2013. Strategi Pembelajaran: Teori dan Aplikasi. Jogjakarta: Ar-Ruzz Media.

Susanto, Ahmad. 2013. Teori Belajar dan Pembelajaran di Sekolah Dasar. Jakarta: Kencana.

Thobroni, Muhammad \& Arif Mustofa. 2012. Belajar dan Pembelajaran Pengembangan Wacana dan Praktik Pembelajaran dalam Pembangunan Nasional. Jogjakarta: Ar-Ruzz Media.

Zaini, Hisyam. 2008. Strategi Pembelajaran Aktif. Yogyakarta: Pustaka Insane Madani. 